\title{
OS REFORMADORES EMPRESARIAIS DA EDUCAÇÃO E A DISPUTA PELO CONTROLE DO PROCESSO PEDAGÓGICO NA ESCOLA
}

\author{
Luiz Carlos de Freitas*
}

\begin{abstract}
RESUMO: Partindo de dois núcleos conceituais constitutivos da organização do trabalho pedagógico (objetivos/avaliação e conteúdos/métodos) examinam-se as implicaçóes dos avanços das propostas dos reformadores empresariais para a educação, evidenciando as conexôes entre as avaliaçóes de larga escala, os processos internos de avaliação (formal e informal) nas escolas, bem como a proposta de redefiniçáo da base nacional comum curricular em curso. Mostrase também que pelo controle do primeiro par dialético (objetivos/avaliação), os reformadores almejam chegar ao controle do segundo par dialético da organização do trabalho pedagógico (conteúdos/métodos). Argumenta-se que sem a discussão e definição prévia de uma matriz formativa, corre-se o risco de reforçar uma matriz meramente conteudista que deixe de fora importantes dimensôes da formação humana na definição de uma base nacional comum.
\end{abstract}

Palavras-chave: Reformadores empresariais. Base nacional comum. Avaliação. Organização do trabalho pedagógico. Formação humana.

\section{THE EDUCATION ENTREPENEURIAL REFORMISTS AND THE DISPUTE FOR THE CONTROL OF THE PEDAGOGICAL PROCESS IN SCHOOLS}

\begin{abstract}
Starting from two conceptual cores, constitutive of the pedagogical work organization (goals/assessment and content/methods) we examine the implications of the advances of the education entrepreneurial reformers proposals, highlighting the connections between large scale assessments (both formal and informal) in schools as well as the proposal for a redefinition of the national curricular common core under way. The article also shows that by means of the first dialectical pair (objectives/assessment) the reformers aim to get control over the second dialectical pair of the pedagogic work organization (content/methods). We argue that without prior discussion and definition of a formative matrix, one runs the risk of reinforcing a matrix which is merely conteudistic and leaves out important dimensions of human development when defining a common national core.
\end{abstract}

Keywords: Entrepeneurial reformists. National common core. Assessment. Pedagogical work organization. Human development.

\footnotetext{
* Universidade Estadual de Campinas, Faculdade de Educação, Campinas, SP, Brasil. E-mail de contato: freitas.lc@uol.com.br.
} 


\title{
LES RÉFORMATEURS D'ENTREPRISES DE L'ENSEIGNEMENT ET LA DISPUTE DU CONTRÔLE DU PROCESSUS PÉDAGOGIQUE A L'ÉCOLE
}

\begin{abstract}
RÉSUMÉ: A partir de deux noyaux conceptuels constitutifs de l'organisation du travail pédagogique (objectifs / évaluation et contenu / méthodes) on examine les implications des progrès dans les propositions des réformateurs d'entreprises pour l'enseignement, en soulignant les liens entre les évaluations à grande échelle, le processus interne d'évaluation (formelle et informelle) dans les écoles, ainsi que la redéfinition proposée de la base nationale commune curriculaire en cours. Il est également démontré qu'en contrôlant la première paire dialectique (objectifs / évaluation) les réformateurs ont pour but atteindre le contrôle de la deuxième paire d'organisation dialectique de travail pédagogique (contenu/ méthodes). On fait valoir que, sans discussion et mise en place préalable d'une matrice de formation, on prend le risque de renforcer une matrice purement de contenu qui laisse de côté d'importantes dimensions du développement humain dans la définition d'une base nationale commune.
\end{abstract}

Mots-clés: Réformateurs d'entreprises. Base nationale commune. Évaluation. Organisation du travail pédagogique. Formation humaine.

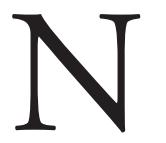

o início da década de 1990 propusemos um programa de pesquisa sobre a organização do trabalho pedagógico partindo das teorias predominantes no campo progressista que procuravam reconstruir a "didática", levando em conta as críticas então vigentes. (FREITAS, 1995)

A motivação se devia ao entendimento de que a organização do trabalho pedagógico da escola que, frequentemente, variava entre as formas típicas da escola tradicional, do escolanovismo e do tecnicismo (SAVIANI, 1983), não eram suficientes para implementar uma educação que conduzisse nossos jovens a se apropriarem dos conhecimentos necessários à vida moderna, nem eram coerentes com uma proposta de educação que visasse seu desenvolvimento integral e que permitisse a eles instrumentalizarem-se para assumir de maneira autônoma e crítica a construção de novas formas de organização social mais justas e solidárias.

Para realizar esta tarefa no campo da organização do trabalho pedagógico, propusemos dois núcleos de categorias fundantes: objetivos/avaliação e conteúdos/métodos. $\mathrm{O}$ processo pedagógico se desenvolveria ao redor destes dois eixos.

Rejeitávamos a proposta de uma interpretação das categorias do trabalho pedagógico, naquela época já em voga, baseada na teoria gerencial e de sistemas que pensava o processo pedagógico de forma linear, guiado por esquemas de retroalimentação destinados ao controle do processo. Por esta via, para alguns, a "melhoria" da escola era um processo iterativo que dependia de boa gestão e 
introdução de tecnologia, o que levou Saviani (1983) a denominar esta abordagem de "escola tecnicista".

Em 1991, ainda no início do impacto das teorias neoliberais na educação, escrevi um texto para a 6a . Conferência Brasileira de Educação onde alertava para a emergência de um neotecnicismo como consequência daquela onda neoliberal que assolava a América Latina e a educação brasileira. (FREITAS, 1992)

Logo em seguida, a área da educaçáo sofreria um esvaziamento teórico e político com a avalanche das propostas pós-modernas que igualmente esvaziariam as meta-narrativas (FREITAS, 2005) e promoveriam a retirada de cena das preocupaçóes com a pesquisa da organização do trabalho pedagógico, a título de que esta reflexão era desnecessária ou seria melhor localizada se produzida no interior da própria pesquisa destinada ao ensino dos conteúdos específicos do currículo da escola. Mais tecnicismo resultou dessa decisão.

A paralização da reflexão sobre o campo da organização do trabalho pedagógico da sala de aula, em suas categorias constitutivas (o chamado "campo da didática"), produziu o espaço necessário para que ele fosse paulatinamente ocupado por aquelas propostas que visavam introduzir melhorias na escola tradicional seja pela via da escola nova ou do tecnicismo, seja por uma combinaçấo destas, o que acabou por contribuir para revigorar, mais recentemente, concepçóes de educação e de escola que considerávamos, pelo menos teoricamente, superadas.

Hoje, volta-se a incentivar fortemente a melhoria das formas didáticas existentes nas nossas escolas - tradicionais em sua maioria - pela via do fortalecimento da gestão e da introdução de tecnologias, acrescidas das teorias de responsabilização e avaliação externas. Está de volta uma nova versão do tecnicismo descrito por Saviani (1983). A disputa pelo campo da organização do trabalho pedagógico da escola, feita com vigor por estas teorias requentadas, pode ser vista a olho nu no interior das escolas.

Tais propostas que nos deixam saudosos das primeiras elaboraçóes da teoria do capital humano dos anos 1970 (SCHULTZ, 1973), foram revitalizadas pela crescente posição da educação como componente das fórmulas de aumento da produtividade e de competitividade das empresas no cenário internacional atual, à medida que a mão de obra barata foi se fazendo escassa no Brasil (ARBACHE, 2011), e os ganhos salariais médios foram aumentando e produzindo impactos nas taxas de acumulação de riqueza da classe empresarial (sem crescimento significativo da produtividade), em um ambiente político de predomínio das teses liberalconservadoras que atingiu todos os setores da vida social e, por conseguinte, a educação. ${ }^{1}$

Mesmo sem acesso pleno à máquina do governo federal nos últimos 12 anos, os impactos desta realidade na política pública foram sendo constituídos via governos estaduais e municipais e por brechas de atuação nos organismos federais, 
sob forte pressão da internacionalização das políticas públicas educacionais. (LIBÂNEO, 2014)

É uma pedra angular destas proposições a implantação das avaliações externas à escola seguidas de processos de responsabilização ${ }^{2}$, como forma de alavancar o aumento das médias de desempenho dos estudantes nas avaliaçóes nacionais e nos exames internacionais. Paulatinamente, com ajuda pesada da mídia, a elevação de médias de desempenho dos estudantes passou a ser aceita como referência do que consideramos hoje uma boa educação (RAVITCH, 2010), sem que uma reflexão crítica sobre as formas de organização do trabalho pedagógico da sala de aula e da escola tenha força para retornar ao debate.

Importa para este novo ciclo observar se ao longo do tempo as médias descem ou sobem e não se as formas de organização das práticas pedagógicas das escolas evoluem em direção a concepçóes avançadas de educação e de participaçáo social da juventude. De fato, procura-se difundir que a questão da educação se resolve a partir de uma gestão eficaz das mesmas formas vigentes de organização pedagógica, associada a novas tecnologias educativas, responsabilização, meritocracia e privatização, motivando a consolidação de um neotecnicismo educacional (FREITAS, 2011), em um grande movimento para adaptar as escolas às novas exigências da reestruturação produtiva e da promoção do aumento da produtividade empresarial que relembra os esforços de John Dewey (DEWEY; DEWEY, 1915) no começo do século passado destinados a adaptar as escolas americanas à nova realidade industrial dos Estados Unidos. Qualquer preocupação acima disto é considerada "pedagogês" desprovido de consequências práticas ou como diz Claudio Moura Castro (2011) "soluços semânticos".

No momento da primeira onda neoliberal no início dos anos 1990, a partir de estudos empíricos na sala de aula (FREITAS, 1995), propusemos ainda que, na escola atual, a categoria da avaliação - no binômio objetivos/avaliaçáo tinha centralidade no processo de organização pedagógica da sala de aula e da escola modulando as demais categorias. Ela não era um mero "fechamento do processo", uma simples "verificação da qualidade do processo pedagógico ocorrido" como se propusera na didática clássica, mas uma categoria que orientava todo o processo do começo ao fim.

Isso assinalava que a superação da forma escolar atual, ou seja, a organização do trabalho pedagógico verbalista, restrita às funçôes sociais de exclusão e subordinação em sua dupla dimensão (na sala de aula e na escola), tinha a ver com a superaçẫo da categoria objetivos/avaliação que funcionava, a mando das funçóes sociais da escola atual, como uma trava potente e um impedimento para a liberação de novas formas para as demais categorias (objetivos, conteúdos e métodos). A avaliação funcionava, então, como uma ancora para as atuais funções sociais da escola, em especial para sua função de subordinação do estudante. 
É esta centralidade da avaliação escolar (fortalecida agora pela associação com a avaliação externa e as políticas de responsabilização) que é disputada e usada hoje pelos reformadores empresariais ${ }^{3}$ da educação para impor uma trava a possíveis avanços progressistas na organização do trabalho pedagógico da sala de aula e da escola - seja em seus objetivos, seja em sua avaliaçáo - fortalecendo seu controle ideológico sobre toda a estrutura educacional que forma milhóes de jovens, ajustando-os a um padrão cultural "básico" de instrução. (ARROYO, 2009)

O primeiro passo foi dado na primeira onda neoliberal na qual os reformadores empresariais asseguraram o papel da avaliação externa nacional e censitária $^{4}$ e a fortaleceram nas últimas duas décadas pela conversão do Instituto Nacional de Estudos Pedagógicos (Inep), órgão do Ministério da Educação, em uma agência nacional de avaliação.

O passo seguinte previsível era tentar controlar o outro elemento do par objetivos/avaliação já que por este elemento, os objetivos de ensino, os reformadores padronizam a cultura escolar através das matrizes de referência dos exames nacionais e travam o avanço das práticas da escola em direçáo a uma matriz formativa mais alargada que lide com a formação integral da juventude, e restringem a escola à matriz clássica, centrada na dimensão do conhecimento.

Como regra, as elites historicamente sonegaram até mesmo a dimensão do conhecimento às camadas populares. Ao longo de décadas o empresariado conviveu muito bem com o analfabetismo e com a baixa qualidade da educação, até que a complexificação das redes produtivas e do próprio consumo demandou mais conhecimento e a máo de obra barata ficou mais difícil de ser encontrada, derrubando as taxas de acumulação de riqueza.

A questáo com a qual o capital passou a se defrontar foi: como liberar um pouco mais de conhecimento para as camadas populares sem abrir mão do controle ideológico da escola, sem correr o risco de eventualmente abrir espaço para as teorias pedagógicas mais progressistas, comprometidas com as transformaçóes da escola para além da versão tecnicista e escolanovista. ${ }^{5}$ Como, em um quadro de escassez de mão de obra barata, incorporar cada vez mais as camadas populares na escola básica, submetendo-a à preparaçâo para o mercado de trabalho?

É esta contradição entre ter que qualificar um pouco mais e ao mesmo tempo manter o controle ideológico da escola, diferenciando desempenhos mas garantindo acesso ao conhecimento básico para a formação do trabalhador hoje esperado na porta das empresas, que move os reformadores a disputarem a agenda da educaçáo, responsabilizando a escola pela falta de equidade no acesso ao conhecimento básico, ou seja, responsabilizando a escola por não garantir o domínio de uma base nacional e comum a todos. ${ }^{6}$ 
Os empresários aceitam a correlação entre pobreza e baixa aprendizagem, mas defendem a tese liberal de que cabe à escola compensar as desigualdades sociais garantindo acesso ao conhecimento, leia-se, garantindo o "básico" para todos, mesmo sabendo que mais da metade das variáveis que afetam o rendimento do aluno estão fora da escola (CARLO, 2010) e que existem complexas interaçóes entre a cultura do entorno das escolas e as próprias escolas. (ERNICA; BATISTA, 2011; ALMEIDA, 2014) Novamente, os reformadores não ignoram estas interaçóes culturais, eles apenas se sentem os "novos colonizadores" que trarão a "boa cultura" às camadas populares imersas na pobreza, na qual mergulharam por demérito próprio ou falta de oportunidade. A isso chamam de "responsabilidade social das empresas". Com isso, tiram o foco da pobreza que eles mesmos geram e colocam os holofotes, primeiramente, sobre a escola.

A defesa do "direito de aprender" do qual somente hoje, após séculos, os empresários se lembraram cumpre várias funçóes, desde as operacionais até as ideológicas. É uma forma de interferir na formação do novo trabalhador e na quantidade de trabalhadores disponíveis ${ }^{8}$, aumentando o controle sobre a escola e ocultando as raízes sociais das desigualdades acadêmicas.

$\mathrm{O}$ direito à formação ampla e contextualizada que todo ser humano deve ter é reduzido ao direito de aprender o "básico" expresso nas matrizes de referência dos exames nacionais, assumido ali como o dominio que é considerado "adequado" para uma dada série escolar nas disciplinas avaliadas - não por acaso as que estão mais diretamente ligadas às necessidades dos processos produtivos: leitura, matemática e ciências. Convém enfatizar que são as matrizes de referência dos exames e não o currículo prescrito, a base nacional comum, que definem o que será considerado como "básico".

No entanto, juntamente com a exigência proclamada do acesso de todos ao básico, pela qual cobram a escola, aceitam em seguida a diferenciaçáo acadêmica no "pós-básico" intrínseca à escala de classificação do desempenho nas avaliaçôes (abaixo do básico, básico, proficiente, avançado) a qual é justificada com fundamento em outra tese liberal: ir além do direito ao básico depende das "aptidóes" e do "dom" das pessoas. Depende do esforço e mérito de cada um. Os liberais náo convivem com a igualdade de resultados, apenas com a igualdade de oportunidades. Com esta lógica, mantêm-se intacto o funcionamento do processo de exclusão, transferindo-se a culpa, agora, para o próprio estudante quando aparecem as "justas diferenças" obtidas pelo mérito de ter aproveitado as oportunidades, para além do básico (obrigatório) esperado na porta das empresas. Ao trabalhador, o básico; às elites, a formação ampla.

É como se garantir ao aluno o acesso ao básico, redimisse a sociedade de ter promovido a desigualdade social que o vitimou, abrindo-lhe as portas do sucesso, agora, na dependência de seu empenho. Daqui para a frente, depende 
dele. No entanto, a promoção da pobreza que colocou a ele e seus pais, desde os primeiros anos de vida, em condição de desvantagem social, não é problematizada pelos reformadores. Qualquer referência a isso é considera uma "desculpa para não ensinar".

Sob a pressão da nova realidade econômica mundial, trata-se, na verdade, de mudar "a altura da vara" que controla o processo de exclusão, permitindo que na sua base mais gente salte por ela ${ }^{9}$, mas sem que ela deixe de cumprir sua função excludente - não só no sentido de eliminação do aluno da escola, o que politicamente é cada vez mais indesejável, mas principalmente no sentido de generalizar a "exclusão por dentro" (BOURDIEU; CHAMPAGNE, 2007) estabelecendo trilhas diferenciadas de progressão no interior do sistema educacional associadas às trajetórias de vida socioeconômicas ${ }^{10}-$, e o mais importante: fazendo isso sem perder o controle político e ideológico da escola e sem mudar as relaçóes sociais causadoras das desigualdades primárias. Eis onde reside a disputa. Tudo a favor do aumento do acesso ao conhecimento (ainda que não só isso) das camadas populares, mas nada a favor da concepção de sociedade, escola e de formação humana que orienta este esforço dos reformadores. Suas concepçóes reforçam a dinâmica social existente, sabidamente insuficiente, e impóem uma padronização do ensino. Por isso evitam discutir estas concepçóes e procuram caracterizar a educação como um grande esforço nacional e suprapartidário - sem ideologia.

Daí que a escola seja, simultaneamente, vista como culpada por náo garantir o padrão "básico" necessário ao novo momento vivenciado pelos processos produtivos, e de outro lado, seja anistiada quando permite a continuidade da segregação acadêmica expressa nas escalas de desempenho (abaixo do básico, básico, proficiente e avançado) em especial no "pós-básico", agora naturalizada e "explicada" pelas características do próprio estudante (o "dom"), ocultando a própria dinâmica do sistema social causadora das diferenças originais, com as quais agora o sistema se reencontra e acolhe. Novos paradigmas de acumulação de riqueza exigem novos paradigmas de exclusão e subordinação. ${ }^{11}$

O que motiva, portanto, esta nova investida dos empresários é resolver a contradição entre a necessidade de padronizar e liberar um pouco mais de acesso ao conhecimento sem com isso perder o controle político e ideológico da escola. E, neste sentido, consideram a si mesmos a própria solução do problema: nada melhor do que eles mesmos assumirem a direção do processo educativo. Isso exige que se desmoralize o magistério e os profissionais da educação, que se mobilize as forças conservadoras e de senso comum da "sociedade" em apoio às suas teses (incluindo os pais), e que se privatize a operação das escolas. (CHUBB; MOE, 1990; RAVITCH, 2011a; FREITAS, 2012) 
$\mathrm{Na}$ primeira onda neoliberal dos anos1990 foi suficiente a elaboração dos Parâmetros Curriculares Nacionais para orientar um sistema de avaliação nacional de larga escala e amostral. Nesta segunda onda em curso, passa-se a defender uma "base nacional comum" associada a uma revisão das matrizes de referência dos exames nacionais, com ênfase na definição das expectativas de aprendizagem por série que leve a uma melhor "amarração" entre os objetivos, a avaliação (agora censitária) e os conteúdos no momento seguinte. ${ }^{12}$

É neste primeiro eixo fundante do processo pedagógico (objetivos/ avaliação) que a disputa com os reformadores se encontra neste momento, face à iniciativa destes para ampliar o papel da avaliação no controle da escola (Lei 13005/2014 do Plano Nacional de Educação) e por definir os objetivos de ensino (através de uma base nacional comum, também incluída no PNE) nos termos de uma matriz formativa que preserve o formato atual da escola e trave o par dialético dos conteúdos/métodos (com apoio da Lei de Responsabilidade Educacional em tramitação no Congresso). ${ }^{13}$

Este conjunto de dispositivos representa o maior avanço dos reformadores empresariais da educação no cenário educacional brasileiro e, entre outros aspectos, visa abrir o campo educacional para "empresas educacionais confiáveis" do mercado de consultoria, materiais didáticos, avaliação, venda de tecnologia, organização de big data entre outras, que operam na difusão de métodos tecnicistas e introduzem nas redes e escolas processos de gestão verticalizados que permitem elevar o grau de controle sobre os profissionais da educação, a título de garantir a obtenção de metas e índices nas avaliações externas, definindo os objetivos, a avaliação, a forma e o conteúdo da escola. No próximo bloco, vamos examinar com mais detalhe como este processo se irradia pelo interior da escola.

Apenas para antecipar a linha geral de análise, consideremos que nesses últimos 20 anos, o grande desenvolvimento das avaliaçóes externas (Prova Brasil, Saresp, Enem, ANA e outras) confirmou a posição de centralidade da categoria da avaliação e revelou outras conexões não imaginadas. $\mathrm{Na}$ luta pelo controle do processo pedagógico das escolas, o Estado é cada vez mais disputado por forças sociais liberal-conservadoras que procuram assumir, por meio de avaliaçóes externas, o controle e o fortalecimento dos processos de avaliação internos da escola (formais e informais) e a partir destes subordinar as categorias do processo pedagógico a seus interesses, vale dizer, preservar e aumentar o controle sobre os objetivos, o conteúdo $e$ até sobre os métodos da escola. A organização do trabalho pedagógico da sala de aula e da escola ficou cada vez mais padronizada, esvaziando a ação dos profissionais da educação sobre as categorias do processo pedagógico, de forma a cercear um possível avanço progressista no interior da escola e atrelar esta instituição às necessidades da reestruturação produtiva e do crescimento empresarial. 


\section{Padronizar, avaliar e controlar o processo pedagógico da escola}

A avaliação ocupou historicamente um lugar central na escola atual como um desdobramento de outra decisão anterior, ou seja, a decisão de isolar a juventude da vida centrando todo o processo de desenvolvimento da criança no interior da instituiçấo escolar e em especial fixando como palco privilegiado do seu desenvolvimento a sala de aula. (DUSSEL; CARUSO, 2003) Privada da aprendizagem em contato com seu meio e das formas "naturais" de avaliaçáo providas pela vida e pela proximidade com o trabalho (FREITAS, 2009), só restou à escola inventar um processo de controle interno na própria instituição que acolhia o processo pedagógico, e a avaliação foi então chamada a cumprir preponderantemente este papel controlador.

Colocar a avaliação nesta posição não foi uma escolha, pois a decisão de separar o ensino da criança da vida foi motivada pela necessidade de afastar a juventude dos problemas ou melhor das contradiçóes sociais com o propósito de fornecer a ela, por antecipação, uma interpretação para tais contradiçôes, antes de que ela mesma desenvolvesse sua própria interpretaçấo, fora do controle dos interesses dominantes. A escola sempre foi um terreno de disputas ideológicas.

$\mathrm{Na}$ atual disputa pela escola, os reformadores empresariais da educação ampliaram a função da avaliação externa e deram a ela um papel central na indução da padronização como forma de permitir o fortalecimento do controle não só sobre a cultura escolar, mas sobre as outras categorias do processo pedagógico, pelas quais se irradiam os efeitos da avaliação, definindo o dia a dia da escola.

Esta nova posição da avaliação, por meio da pressão de exames nacionais e internacionais, fortaleceu a lógica de alinhamento da escola a determinadas concepçôes didáticas que julgávamos superadas e tornou possível que a internacionalização das políticas públicas (LIBÂNEO, 2014) tivesse efeito. Baseia-se na imitação da organizaçáo do trabalho da iniciativa privada, onde o controle do processo recebe atenção privilegiada a partir da padronização e automação das atividades, tornando o trabalhador um apêndice substituível da máquina e seu desempenho monitorado por indicadores de qualidade que, se atingidos, autorizam recompensas definidas e contingentes aos índices (recompensas sociais e financeiras).

Claudio Moura Castro (2011) estabelece tal relação de forma simples e clara ao escrever que:

É irrelevante perder tempo indagando se a escola tem "produto", se ensino é "mercadoria", se "produtivismo" é neoliberal e outras fantasias do mesmo naipe. Importa reter que instituiçóes das 
mais variadas naturezas e índoles têm muito em comum e que há boas regras e ferramentas que servem para todas. Como o setor produtivo se antecipou aos outros, há excelentes razóes para aprender como ele. Com efeito, quem entendeu isso está ganhando qualidade.

E a receita é rápida e simples:

Nos últimos anos, explicitam-se os critérios da boa gestão: 1) Definir objetivos claros (o piano sobe ou desce?); 2) quantificar as metas (sem medir náo sabemos onde estamos); 3) compartilhar as metas com os colaboradores; 4) criar instrumentos para acompanhar o funcionamento, passo a passo; e 5) criar mecanismos para premiar, punir e corrigir os desvios.

Este resumo da "metodologia" proposta, embora simplificado, é emblemático e permite ver de onde vem a necessidade da criação de mecanismos de padronização e controle do processo de ensino-aprendizagem da escola. Entre estes mecanismos encontram-se os exames de larga escala em todos os níveis educativos e, mais recentemente, a retomada da discussão do currículo da educação básica na forma de uma "base nacional comum"14 a ser induzida dentro de um "pacto federativo" para todos os Estados ${ }^{15}$. Ou seja, neste momento o embate concentra-se na disputa pelo primeiro par dialético da organização do trabalho pedagógico, vale dizer, no binômio objetivos/avaliação, com forte ancoragem nos processos de avaliação externa, como forma de fortalecer e direcionar a avaliação interna das escolas e, através dela, avançar para o segundo par dialético - conteúdos/métodos. As mediaçóes internas criadas por esta abordagem são apoiadas em processos de gestão verticalizados igualmente inspirados pela lógica empresarial. ${ }^{16}$

Hoje é fato visível nas escolas que a avaliação externa orienta e determina os objetivos e a extensão das disciplinas (em especial português e matemática, mas não menos as demais disciplinas pois que interfere nos tempos que a escola permite dedicar a estas). A repercussão nas outras categorias pedagógicas vai se estabelecendo por meio da pressão crescente das avaliaçóes externas que influencia o quê o professor e a escola assumem como conteúdo e como método.

A disputa pelo processo pedagógico se dá em confronto com movimentos organizados de empresários para quem o momento exige a indução de objetivos de ensino claramente definidos e quantificáveis ${ }^{17}$ através de processos de avaliação nacionais (e não mais como temos hoje, "parâmetros curriculares nacionais" que, para eles, não respondem às novas necessidades que a escola deve assumir face ao desenvolvimento econômico). 
O controle e a padronização dos conteúdos e métodos já podem ser observados e estão manifestos na intensificação dos processos de apostilamento (ADRIÃO et al, 2009) e pela contratação de empresas de consultoria, a título de melhorar índices do Ideb, portanto em sintonia com a pressão exercida pelas avaliaçóes externas.

Estas ações impostas ao interior da escola têm por base a intensificação da padronização da atividade pedagógica como forma de viabilizar o controle ideológico da escola (AU, 2009). Há, portanto, uma disputa pela escola entre pelo menos duas visóes: a dos reformadores empresariais da educação que adotam o modelo resumido por Castro (2011), indicado acima, e os educadores que por formação rejeitam a possibilidade de que o processo educativo seja reduzido à teoria da organização das empresas privadas, bem como suas formas de gestão e recusam a reedição da teoria do capital humano como base para a organização da formação humana.

A emergência da segunda geração da teoria de medição, conhecida como Teoria da Resposta ao Item (TRI), reforçou este direcionamento, pois permitiu lidar com maior precisão com a produção, aplicação e processamento dos itens de avaliação das provas (calibração de itens). Tais processos são vitais na padronização dos resultados da aprendizagem e, por medirem "traços latentes", têm a vantagem de poder descolar-se de um determinado conteúdo específico medindo competências e habilidades latentes no desenvolvimento da aprendizagem.

Além disso, foi possível aumentar o grau de comparabilidade entre avaliaçóes de diferentes populações de estudantes em diferentes momentos de aplicação (equalização), dando maior consistência aos processos de acompanhamento da evolução das aprendizagens ao longo dos anos de estudo.

Mais importante ainda foi a possibilidade de traduzir o desenvolvimento da aprendizagem em escalas de proficiência (abaixo do básico, básico, proficiente, avançado), pelas quais se pode posicionar um determinado aluno em relação ao conjunto da população medida e fornecer elementos que caracterizem a aprendizagem do estudante do ponto de vista pedagógico, a partir de uma análise que tenha como base a matriz de referência que deu origem ao exame e as respostas dos estudantes.

Tudo isso configurou um avanço significativo nas técnicas de medição e avaliação. Ao mesmo tempo, permitiu um maior controle sobre o processo educativo e igualmente sobre a padronização do conteúdo da escola e de seus resultados.

Os reformadores empresariais apostam na criação de uma conexão direta entre as avaliações externas da escola e uma série de mediaçóes e medidas complementares que têm lugar no interior da escola em processos de avaliação intraescolar específicos. 
Tais processos avaliativos no interior da escola se diversificam em procedimentos de caráter formal e informal e abrangem diferentes dimensões. (FREITAS, 1995) Em geral, a avaliação mais conhecida é a que examina quanto o aluno aprendeu de um determinado conteúdo ensinado, a avaliação da aprendizagem. Mas isso está longe de cobrir toda a gama de processos avaliativos da sala de aula. Há muito mais que isso. Pelo menos outras duas dimensões estão permanentemente sendo avaliadas: o próprio comportamento do aluno na sala e seus valores e atitudes.

Até agora, as avaliaçôes de larga escala incidiram na primeira dimensão do processo de avaliação em sala de aula, a da aprendizagem, mas já há movimentos expressivos destinados a se criar avaliação de larga escala para outras dimensóes, chamadas de "socioemocionais" e que dizem respeito, em especial, aos valores e atitudes dos estudantes. (ANPED, 2014)

No interior da sala de aula o professor lida o tempo todo com estas três dimensóes da avaliação (aprendizagem, comportamento e valores) por meio de processos que podem ser tanto formais (provas, testes, trabalhos etc.) como informais (juízos de valor sobre o comportamento do aluno ou sobre seu desempenho, comentários públicos ou dirigidos especificamente ao aluno em atenção individualizada etc.).

Os processos formais são pontuais, mas os processos informais são contínuos e distribuídos durante toda a ação pedagógica do professor, ou seja, ocorrem ao longo do próprio processo de ensino/aprendizagem. Seu poder - de apoiar ou destruir - é muito maior pela sua frequência e pela natureza pública que assume na maior parte das vezes, expondo o desempenho do estudante ante os demais alunos.

É neste ponto que a avaliação externa de larga escala se conecta com a avaliaçáo interna à escola e modula, em especial, os processos de avaliação informal atingindo os professores e a criança.

As relações entre as avaliações externas de larga escala e as avaliaçôes formais internas à escola ocorrem em vários momentos, mas, especialmente, no que conhecemos como "simulados" destinados a preparar para os testes e também na organização das provas internas regulares da escola que acabam voltando-se para o mesmo objetivo. As consequências mais duras, no entanto, são potencializadas quando as avaliaçóes de larga escala se conectam às avaliaçôes informais feitas pelo professor durante o processo de ensino em sala de aula.

O papel das avaliaçóes informais é decisivo no progresso das crianças. Pode-se mesmo dizer que ao ser reprovado pela avaliaçâo formal (seja interna ou externa) o aluno foi reprovado, antes, na relação de ensino a qual é perpassada pela avaliação informal. Este processo cria, em sala de aula, um histórico de juízos de valores que sáo definidores das possibilidades de progresso dos alunos, pois afetam 
as estratégias metodológicas seguidas pelo professor e a forma de envolvimento dos estudantes. Sáo estes processos que conformam culturalmente o aluno ou promovem o seu afastamento. Pela avaliação informal o professor cria nas relaçóes de ensino uma autoimagem da criança e produz uma autoimagem também na criança. A autoimagem é um poderoso instrumento de motivação ou desmotivação, na dependência de seu conteúdo, e tem relação com a própria identidade cultural do estudante.

Quando a avaliação externa pressiona o professor por maior desempenho em sala ou quando o seu salário está associado ao sucesso da criança nas provas da avaliação externa, ela interfere irremediavelmente nesta relação e sela o destino da criança. Não bastasse isso, as pressóes externas da avaliação levam a escola a criar mecanismos concorrenciais internos de controle sobre as crianças, como por exemplo, a divulgação dos alunos e professores que se saíram melhor nos exames externos. Às vezes, listas são afixadas nas salas de aulas ou em outros locais da escola.

Estas açóes reforçam aquelas feitas pelos professores no interior do processo de ensino diretamente com o aluno. Em determinadas situaçóes as crianças, em função de seu desempenho, circulam constantemente entre turmas consideradas "fracas" ou "fortes" durante o ano ou são encaminhadas para "reforço" sendo, portanto, identificadas pelos demais colegas. E da mesma forma que existe uma avaliação informal das crianças pelos professores, há uma contínua avaliação informal entre as próprias crianças. Quem já vivenciou tais processos nas escolas sabe que eles podem chegar a ser violentos e depreciativos. A escola se transforma em um local aversivo para quem tem problemas de aprendizagem ou não se ajusta à cultura escolar oficial, independentemente de boas intençôes.

As avaliaçóes externas conectam-se com este processo complexo que ocorre, predominantemente, no interior da sala de aula para controlar o processo pedagógico - mas que tem suporte no planejamento da própria escola quando ela reage aos resultados das avaliaçóes externas, através das avaliaçóes internas.

$O$ fato das escolas agirem sob motivação externa sem que haja um movimento na própria cultura da escola que se aproprie de seus problemas, reflita, recrie e participe dos processos de melhoria, bloqueia e agrava as relaçóes de ensino. A associação entre desempenho dos alunos e pagamento dos professores, seja como salário variável, seja como bônus anual, por exemplo, turbina definitivamente esta rede de relaçóes que se torna conflitiva e concorrencial.

É no plano da avaliação informal que se joga o destino dos estudantes, marcados por sucessivas microaçóes no interior da sala de aula e da escola. Processos de exclusão são postos em marcha consolidando os estudantes em trilhas de progressão que nem sempre conduzem ao sucesso. 
Neal e Schanzenbach (2010, p. 266) conduziram um importante estudo sobre os impactos dos processos de responsabilização na atuação dos professores em sala de aula. Dizem os autores:

Porque a linha de base da instrução para todos os estudantes náo é uma variável de escolha da escola, o problema da escola é minimizar o total de custo acarretado pela alocação de instrução extra entre seus estudantes e as penalidades associadas com o fracasso dos estudantes. [...] As formas específicas da função penalidade, o custo da função, a distribuição dos tipos de habilidades, e a distribuição dos erros de medida interagem para determinar o exato modelo de investimento ótimo. [...] $\mathrm{O}$ foco do nosso trabalho empírico é a afirmaçáo de que os sistemas de responsabilização construídos em torno da contagem da proficiência incentivam as escolas a dar ajuda extra para os estudantes que estão no meio da distribuição de habilidades e dá poucos incentivos para as escolas dirigirem atenção extra para os estudantes que estão muito abaixo da proficiência ou já são proficientes.

Ou seja, não resolvem o problema das brechas de aprendizagem especialmente em relação às crianças mais pobres que são a grande "inspiraçáo" dos reformadores empresariais da educação para introduzir as políticas de responsabilização.

As avaliaçóes externas, portanto, têm consequências não controladas dentro das escolas e suas salas de aula e constituem parte de uma cadeia de açóes que afeta a vida de professores, estudantes, diretores e pais de alunos. Neste processo rompem-se importantes pressupostos da relação e da confiança entre profissionais e entre estes e seus estudantes.

Bryk e Schneider (2002) criaram um importante conceito - confiança relacional - nascido nas experiências de Chicago no final da década de 1980 e ancorado em trabalhos de Robert Putnam e James Coleman. Por esta proposição,

[...] a participação social não vincula apenas benefício material aos indivíduos, mas também importantes recompensas sócio psíquicas. [...] Os professores atribuem grande importância às recompensas psicológicas associadas ao seu trabalho. (p. 15)

Ainda segundo os autores, a confiança relacional vê as trocas sociais de escolarização organizadas ao redor de um

[...] conjunto de papeis afins: professores com estudantes, professores com outros professores, professores com pais de aluno 
e com seu diretor. Cada parte mantém um entendimento de suas obrigaçóes e tem alguma expectativa sobre as obrigaçóes de outros. A manutenção (ou crescimento) da confiança relacional em um dado papel requer sincronismo nestas obrigaçôes e expectativas mútuas. (p. 20)

Neste sentido, continuam os autores, a dinâmica da confiança relacional está baseada numa combinação de quatro fatores: respeito, competência, consideração para com os outros e integridade. Uma deficiência em um destes critérios compromete a relação toda. (BRYK; SCHNEIDER, 2007, p. 23)

Os processos de responsabilização concorrenciais rompem a confiança relacional ao exporem indevidamente o desempenho de gestores, pais, professores e alunos: se os alunos aprendem os professores são responsáveis; se não aprendem os professores também são responsáveis; se os alunos não aprendem os professores tendem a culpabilizar o próprio aluno ou os pais ou a falta de condiçóes de trabalho; os gestores livram-se de pressão superior rolando a culpa para baixo, em direção a professores, alunos e pais. No meio de tal deterioração nas relações, emerge a fraude. Alunos são estimulados a procurar outra escola; outros são "escondidos" nos dias de prova; professores são estimulados a mudar de escola pois "estão derrubando as médias e o bônus da escola" etc. (NICHOLS; BERLINER, 2007).

A sala de aula e a escola não são uma linha de produção sobre a qual pode-se cravar uma série de relógios que indicam se a produção está sendo feita segundo as metas ou se está havendo algum "desvio". Muito diferente disso, a escola e a sala de aula se assemelham a uma rede de relaçóes multilaterais que não deve sofrer interferências não planejadas de fora, e na qual as açóes devem ser acordadas, ou seja, negociadas entre os variados participantes do processo. Açóes não planejadas de fora para dentro destroem a confiança relacional vital para o desenvolvimento de um trabalho que é antes colaborativo entre seus participantes. A ideia da concorrência que orienta os negócios dos empresários e que se expressa no "premiar, punir e corrigir os desvios da meta" não é boa para a educação, simplesmente porque esta não é uma atividade concorrencial.

A padronização e o controle atingem todas as categorias do processo didático. Além destes impactos na categoria da avaliação, existem impactos sequenciais nas outras categorias. Já antecipamos como ela afeta os conteúdos por meio de duas ações combinadas: impondo restrições à amplitude do conteúdo de uma disciplina a ser ensinada pelo professor, incluída aí a interferência em seu ritmo de aprendizagem, e o estreitamento curricular que foca o ensino nas disciplinas avaliadas. (AU, 2007)

No primeiro caso, como em todo processo de avaliação, os testes precisam fazer escolhas sobre o que incluir na avaliação (as matrizes de referência da 
avaliação), pois não podem abarcar tudo. Ao fazer escolhas, cria-se uma tradição de exame que ao longo do tempo influencia o que é dado em sala de aula. (MADAUS; RUSSELL; HIGGINS, 2009) Essa tradição é reforçada nos simulados, tentando prever o que cairá na próxima avaliação em função do passado.

A pressão externa, sob o argumento do "direito de aprender", impóe uma cultura escolar e define o ritmo de ensino do professor em sua sala, marcado pelas avaliaçóes locais preparatórias para as avaliaçóes em larga escala. Este processo é controlado pelos gestores das escolas que não só acompanham o avanço do desenvolvimento do conteúdo nas salas de aula através das apostilas, como definem quando ocorrerão simulados e avaliaçóes locais (não raramente de periodicidade bimestral) em articulação com avaliaçóes externas.

A definição do ritmo de fora para dentro expropria as decisóes pedagógicas do professor em relação às dificuldades que percebe em seus estudantes e estabelece uma velocidade de avanço que o obriga a postergar para momentos futuros os processos de recuperação do aluno para dar conta do ritmo externo imposto à escola. O professor é privado de dar o "reforço" no ato da aprendizagem. Quanto mais se impóe um ritmo único para a aprendizagem das crianças, maior a possibilidade de diferenciação dos desempenhos, já que o ritmo único é, pedagogicamente, um indutor de exclusão. (BLOOM; HASTINGS; MADAUS, 1971)

Pressionado a garantir a aprendizagem em uma escola de tempo parcial e sem suporte adequado, o professor avança no tempo que deveria ser ocupado para ensinar outras disciplinas que não caem no exame, para poder dar conta daquelas que caem no exame. Sobrevém o estreitamento de disciplinas do currículo o que implica em sonegação de conhecimento que não entram no exame, em nome da garantia de aprendizagem do básico em português e matemática, que caem no exame. Neste quadro, o básico se define mais em função do que exclui do que daquilo que ele de fato contém. O direito de aprender se converte, quando bem sucedido, em um direito de acessar o conhecimento básico das matrizes de referência de avaliação e, mesmo assim, em algumas disciplinas. ${ }^{18}$ A sonegação histórica do conhecimento às camadas populares, a despeito dos discursos, se impóe.

Entretanto, os processos de avaliação da aprendizagem dos conteúdos não esgotam, como vimos, as dimensóes da avaliação na sala de aula. Ainda temos os processos de avaliação do comportamento do aluno e as avaliaçóes de valores e atitudes.

Em relação a estes, o que se observa em países que já fazem uso destas abordagens, é que os processos de responsabilização tendem a recuperar procedimentos de controle conservadores sobre o comportamento e sobre os valores dos alunos. A padronização vai além do conhecimento. Tais processos estáo hoje evidentes nas tentativas de se elaborar a avaliação de larga escala das chamadas "habilidades socioemocionais", ou em pressóes que são feitas junto à família para 
que controlem valores e atitudes das crianças na escola, sob pena de perderem a vaga. O clima escolar vai ganhando contornos que revelam a intensificação do controle disciplinar onde a obediência (e não a auto-organização dos estudantes) é valorizada. Tudo que for diferente do padrão cultural assumido é considerado indisciplina, ou comportamento inadequado a ser "corrigido". (ARROYO, 2009)

Mais uma vez, o cenário norte-americano é bem esclarecedor desta tendência e é retratado pelo movimento conhecido como no excuses - "sem desculpas" ou ainda "tolerância zero". Nas palavras de Diane Ravitch (2013):

[...] a origem do "No excuses" pode ser atribuída a um livro do mesmo nome por Samuel Casey Carter, escrito em 2000, acerca de "21 escolas de alto desempenho e alta pobreza" e divulgado pela Heritage Foundation de extrema-direita. A ideia por trás do livro é que nós não precisamos gastar mais dinheiro para consertar as escolas, temos apenas que nos certificar de que as escolas sejam exigentes em sua disciplina e sem nenhum absurdo pedagógico.

Obviamente, os mesmos efeitos que a avaliação externa dos conteúdos cognitivos causam na escola e na sala de aula, também serão encontrados na avaliação socioemocional, direcionada para a padronização de valores e atitudes dos estudantes.

Recentemente uma carta aberta da Associação Nacional de Pesquisa e Pós-Graduação (Anped) fez uma série de questionamentos em relação a este tipo de avaliação em larga escala:

- [...] as dimensóes política e ideológica são constitutivas da avaliação, ou seja, é uma atividade que traz inerente às suas finalidades e procedimentos a afirmação de valores, que representam projetos educacionais. Que valores são afirmados por meio dessas avaliaçôes? A quem cabe defini-los?

- O estabelecimento de uma hierarquia valorativa, pretensamente universal e imparcial, expressa a desconsideração da desigualdade social econômica e a diversidade cultural da sociedade brasileira, bem como as diferenças entre os sujeitos, o que possivelmente representa a naturalização de valores oriundos das classes mais favorecidas. $\mathrm{O}$ que se busca é a padronizaçáo desses valores?

- As avaliaçóes em larga escala vêm se constituindo como uma das principais estratégias de consecução de uma lógica de gestão da educação que, em nome da promoção do desenvolvimento dos alunos, recorre à comparaçáo de seus níveis de proficiência e à sua classificação e premiação. O que poderá resultar da avalia- 
ção de habilidades socioemocionais: premiação daqueles alunos que se conformarem aos valores estabelecidos? Segregação e discriminação daqueles que não apresentam as habilidades tomadas como as necessárias para uma sociedade "melhor"? Quem decide sobre qual é a "melhor sociedade" são os elaboradores dos itens dos testes?

- É conhecido o potencial das avaliaçóes externas à escola, em larga escala, de condicionarem e conformarem o currículo. O que teremos agora: a intensificação e ampliação desse controle e conformação, abarcando um quadro disciplinar de competências socioemocionais tidas como desejáveis?

- Corre-se o risco de rotular e estigmatizar crianças e jovens por não se saírem bem nos testes socioemocionais, culpabilizando-os pelo fracasso, abstraindo fatores contextuais, sejam suas condições de escolarização, seja seu capital econômico, social. Em consequência, não se estaria afirmando preconceitos a respeito de determinados estudantes?

- O desenvolvimento socioemocional ou socioafetivo é, assim como o cognitivo, um processo de construção do sujeito, intermediado por questôes sociais, culturais, ambientais que não pode ser medido por meio de itens de testes de larga escala. $\mathrm{O}$ que se intenta é torná-lo mensurável e quantificável para apoiar classificaçóes? (ANPED, 2014)

A centralidade da categoria da avaliação, agora fortemente ancorada também nos processos de avaliação externa na versão dos reformadores empresariais da educação que cada vez mais ganha espaço nos meios educacionais, vem fortalecer o controle ideológico dos espaços da escola, a mando das atuais funçóes sociais da escola, ou seja, a promoção da exclusão e da subordinação a determinados valores e comportamentos padronizados.

Pelo caminho da "exclusão por dentro" (BOURDIEU; CHAMPAGNE, 2007), criam-se trilhas de progressão diferenciadas que levam os estudantes a diferentes trajetos de qualificação/desqualificação, legitimando práticas de classificação no interior da escola (abaixo do básico, básico, proficiente e avançado). Pelo caminho da subordinação recuperam-se práticas de controle social conservadoras baseadas na submissão pelo disciplinamento (habilidades socioemocionais). ${ }^{19}$

As visóes alternativas de organização do trabalho pedagógico no interior da escola vão ficando cada vez mais sem espaço para se manifestar ante o peso avassalador das avaliaçóes externas, consultorias e materiais pré-fabricados que engessam a atividade da escola e se associam a processos de mediação internos, ancorados em uma gestão verticalizada e que funcionam como transmissores daquelas funções sociais de exclusão e subordinação, através de microações que redefinem 
as relaçôes entre os atores escolares, controlando os objetivos, os conteúdos e os métodos de ensino. Qualquer ação fora do esperado pode comprometer a nota da escola e/ou o bônus de final de ano. ${ }^{20}$

O diretor da escola se transforma em um animador que controla metas previamente "comunicadas aos colaboradores" com processos bem definidos e controlados "passo a passo", de forma a "premiar, punir e corrigir desvios". Esta é a escola com a qual o tecnicismo sonhou e que o neotecnicismo realizou. (FREITAS, 1992; 2013)

Cabe agregar que, em relação aos profissionais da educação, opera-se a mesma desqualificação que ocorre no interior dos processos produtivos com a introdução de novas tecnologias e com os controles gerenciais, ou seja, os profissionais vão tornando-se facilmente substituíveis e, portanto, aligeira-se a sua própria formação profissional.

Neste particular, caminha-se na direção de afastar as universidades do processo formativo dos profissionais da educação, redirecionando-os para instituiçóes cuja base teórica restrita impeça de formá-los dentro de uma perspectiva mais avançada e crítica, alinhando sua formação às exigências restritas do domínio do conteúdo expresso no currículo oficial. ${ }^{21}$

O controle gerencial verticalizado nas escolas, o apostilamento e o planejamento "passo a passo" fazem com que seja desnecessária uma grande preparação profissional, bastando que professores improvisados treinados em seguir apostilas e obedecer sejam suficientes para os novos propósitos. Já não é necessário adequar o desenvolvimento da aprendizagem aos vários e diferenciados ritmos de aprendizagem dos estudantes - para tal existem as classes de reforço onde outro profissional lida com os mais lentos; sistemas on line apresentam programas de reforço para cada uma das dificuldades dos alunos; alguns simplesmente são colocados em trilhas de progressão que os levam a aguardar pela exclusão em algum ponto do sistema que não incomode as estatísticas.

Onde os reformadores controlam a educação, o regime de contratação de professores sofre modificação radical, já que a proposta destes não consegue se concretizar totalmente sem que se elimine a estabilidade no emprego dos professores, pois com estabilidade ele não pode ser demitido como prevê a "eficácia empresarial". Para tal é necessário que a escola pública seja privatizada ou passe a contratar por regimes que permitam a demissão sumária do professor considerado "ineficaz". (PARCEIROS DA EDUCAÇÃO, 2010) Por esta mesma via, chega-se também ao fechamento de escolas consideradas "ineficazes" e sua substituição por concessóes à iniciativa privada via organizaçóes sociais. (CENTRO DE DEBATE DE POLÍTICAS PÚBLICAS, 2014) 


\section{Da falta de evidência ao debate ideológico: questionando a matriz formativa}

Na primeira fase do debate com os reformadores empresariais, foi necessário trazer à tona em vários momentos a falta de evidência empírica que fragiliza as propostas de política pública feitas por esta tendência educacional ${ }^{22}$ (FREITAS, 2012), bem como as inadequaçóes éticas de aplicá-las a redes inteiras sem o suporte de tal evidência, aliada à ampla literatura que atesta seus efeitos colaterais deletérios. (RAVITCH, 2013a; FREITAS, 2013; 2013b; GUISBOND; NELL; SCHAEFFER, 2012; ROTHSTEIN, 2008; NICHOLS; BERLINER, 2007)

$\mathrm{O}$ acirramento do debate sobre os objetivos de ensino na forma de uma "base nacional comum" ou na forma de "direitos de aprendizagem", como gostam de pautar os reformadores, nos leva a trazer para a cena novos níveis de análise, pois o debate da base nacional comum é um debate, para ambos os lados, ideológico - ou seja, cujos posicionamentos dependem da visáo de mundo que cada um dos lados em disputa tem sobre o papel formativo da escola. Esta postura ideológica materializa-se na concepçấo de educação e na matriz formativa que fundamentam as proposituras e que precisam ser tornadas públicas, para elevar o nível do próprio debate e evitar a sua redução a uma lista de objetivos e conteúdos padronizados. ${ }^{23}$

A postura ideológica dos reformadores empresariais não passa daquela já formulada no começo do século passado pelo liberal e pragmatista John Dewey (DEWEY; DEWEY, 1915) e seus três "princípios morais". Shulgin (2013) após citar longo trecho deste autor, critica pertinentemente sua proposição:

A questão geral sobre a correspondência da educação e da formação às condiçóes de vida modernas - diz Dewey - agora se torna particularmente grave, em função do desenvolvimento industrial. Diferentes detalhes da questão podem conduzir a três disposiçôes gerais, a três princípios morais.

Primeiro: nunca antes foi táo importante como agora que cada indivíduo seja apto para um trabalho consciente, provocante e respeitado para seu ganha-pão, isto é, nós todos precisamos ganhar a vida para nós e para os nossos próximos e fazê-lo com respeito ao nosso trabalho e com interesse na execuçáo consciente do trabalho.

Segundo: nunca antes o trabalho de um indivíduo produziu efeito sobre o bem-estar dos outros em tal medida como agora. As condiçóes modernas de produçáo e troca de produtos unificaram o mundo como nunca antes. (...) Por isso mesmo é agora apresentada à escola a exigência, anteriormente desconhecida, de que cada parte do ensino escolar esteja relacionada a uma complexa rede de atividades sociais, que liga as pessoas 
umas com as outras. Quando elas viviam em pequenos grupos independentes, o dano da escola ocupada exclusivamente com questóes teóricas e intelectuais foi comparativamente insignificante. $\mathrm{O}$ conhecimento pôde ser isolado, porque as próprias pessoas viviam isoladamente. Mas em nosso tempo, a simples acumulação de informaçôes, sem relação com as condições sociais de vida, é mais do que inútil. A aquisição de habilidades e técnicas qualificadas sem entender como usá-las para a sociedade é quase criminosa.

Terceiro: os métodos de produção e processos industriais agora são baseados, em uma extensão muito maior do que antes, no conhecimento dos fatos e das leis das ciências naturais e sociais. As nossas ferrovias, navios, barcos a vapor, telégrafos, telefones, fábricas, fazendas, até mesmo dispositivos domésticos comuns têm base em complexas estruturas matemáticas, físicas, químicas e biológicas e dependem, para melhor uso, do entendimento de fatos e relaçóes da vida social. [...]

De modo que a questão aqui se torna tão vasta e complexa que é impossível resolvê-la. (SHULGIN, citando DEWEY; DEWEY, 1915, p. 115-116) [grifo nosso].

Está claro dessa forma [prossegue Shulgin] que Dewey enfrenta uma contradição insolúvel; ele entende que o desenvolvimento econômico do mundo impóe à escola exigências que não são viáveis dentro do regime democrático existente. "Impraticáveis", "impossíveis", elas exigem mais do que deseja Dewey. E ele? Ele não quer se separar do sistema existente, lutar pelo futuro; não, ele quer "atenuar as contradiçóes", "adaptar". Esta é a meta principal de sua filosofia. Este é o núcleo de seu sistema de ensino. "Cabe lembrar - diz ele - que a nossa tarefa é apenas a adaptação, o estabelecimento da correspondência, e não a criatividade. (DEWEY; DEWEY, 1915, p. 116, apud SHULGIN, 2013, p. 29-30)

Os atuais reformadores empresariais apenas retomam esta filosofia pragmatista do começo do século passado em outros níveis de exigência tecnológica e de controle social e lhe dão aparência de "inovação" - no fundo, trata-se novamente de adaptar a escola às exigências oriundas do mundo do trabalho e, em especial, ao aumento da produtividade de forma a recompor taxas de acumulação de riqueza.

Estamos aprofundando aquela primeira onda neoliberal no âmbito da educação, conduzida ainda por Paulo Renato Costa Souza e sua equipe quando estiveram no Ministério da Educação dentro do governo de Fernando Henrique Cardoso. [N.E.: 34a . Presidente da República Federativa do Brasil, 01.01.1995 a 01.01.2003]. 
Nesta segunda onda neoliberal na educação, os reformadores chegam agora com mais força pela experiência que acumularam em 20 anos de atuação sistemática, não só no Brasil, mas especialmente dentro dos Estados Unidos (EMERY, 2002; RAVITCH, 2011a) e pelo fato de que há novos mecanismos de pressão atuando na direção da internacionalização da política educacional, dentre os quais se destacam a Organização para a Cooperaçâo e Desenvolvimento Econômico (OCDE ) e as ramificações nacionais expressas por organizaçōes locais dirigidas e financiadas por empresários, como o Movimento Todos pela Educação no Brasil.

Estes atores, embora antigos, atuam agora com maior força dentro dos órgãos nacionais de elaboraçáo de políticas educacionais, Ministérios, Congresso Nacional e articulam expressivo apoio da mídia liberal/conservadora, que veicula cotidianamente suas propostas, sem contar o apoio de inúmeras empresas educacionais de consultoria, ONGs e institutos privados.

Teoricamente o limite deste movimento é o mesmo de J. Dewey, entretanto, do ponto de vista prático, conta com mecanismos jamais pensados por aquele teórico. Causa estranheza, no entanto, que os reformadores empresariais tomem de Dewey o pragmatismo da adaptação da escola às necessidades da sociedade vigente, mas somem a ele o neotecnicismo com sua ênfase na padronização e controle, restringindo até mesmo a proposta da escola nova formulada por Dewey, que apostava na autonomia do professor como forma de promover o trabalho independente dos estudantes.

Porém, a questáo de fundo que devemos colocar neste momento em que os reformadores estão pautando a discussão do primeiro par constitutivo da organização do trabalho pedagógico (objetivos/avaliação) é a seguinte: qual é o nosso horizonte social? Qual é o projeto de nação que temos para nossa juventude? Adaptar-se às necessidades do próprio capital, como propunha J. Dewey, e acreditar que a própria evolução científica e tecnológica resolverá naturalmente as contradiçóes sociais que se acumularam? Serve esta visão edílica de mundo para aqueles que hoje sofrem duramente os efeitos da configuração das forças sociais vigentes? Devem eles aguardar ou devem eles se engajar na construção de um futuro que atenda a seus interesses emancipatórios que vão muito além de ter uma vaga em uma empresa, ou tornar-se "empregável"? E se devem ser sujeitos ativos que interfiram nos destinos da organização social, serve uma escola que combine adaptação social com conservadorismo metodológico e moral na forma proposta pelos reformadores empresariais, ou devem exigir uma escola que permita que se desenvolvam como lutadores e construtores de outras relaçóes sociais, facultando a emersão de outras formas de organização social que efetivamente superem as injustiças que estão na base constitutiva de nossa sociedade e que são as reais travas para que a educação possa, de fato, cumprir seu papel emancipador? 
Para cada uma destas visôes de mundo, há uma organização pedagógica do trabalho da escola diferente a ser pensada: uma delas, a dos reformadores, aposta na adaptação da escola a novos paradigmas de exclusão e de subordinação; a outra, defendida por grande número de educadores progressistas, aposta na transformação social e para tal, não propóe mera adaptação, mas sim a mobilização da escola para a construçâo de alternativas sociais; para o desenvolvimento da solidariedade e não da competiçáo e da concorrência; para a valorização da auto-organização do estudante e do trabalho coletivo; bem como o respeito à diversidade cultural e não a padronização da cultura escolar.

As consequências mais diretas destas ideologias ou visóes de mundo, atingem exatamente a própria constituição da matriz formativa que orientará a organização do trabalho pedagógico e a escolha dos "direitos de aprendizagem". Projetos diferentes, direitos diferentes. Portanto, há exigências e escolhas anteriores a serem debatidas, já que a matriz escolhida tem efeito sobre a amplitude das aprendizagens incluidas e que seräo consideradas "direitos".

Passando por alto esta questáo, os reformadores querem logo definir os objetivos de ensino, sem uma reflexão sobre os objetivos da formação humana que orientam as dimensôes de uma matriz de formação que paute a amplitude da experiência formativa das crianças e jovens.

Pelo lado dos reformadores, a matriz formativa proposta é restrita à dimensão do cognitivo. Cientes de sua limitação, camuflam todas as demais dimensôes da formação sob o título de "habilidades socioemocionais" e, com isso, reduzem as outras dimensóes a um conjunto de comportamentos novamente adaptativos.

Pelo lado dos que se contrapóem a esta visão, a proposta inclui uma matriz formativa que não restrita ao cognitivo mas que inclui, além desta dimensão, a formação para a criatividade, a afetividade, o desenvolvimento corporal e as artes e se expressa em uma organização do trabalho pedagógico que inclua as dimensôes do conhecimento, da diversidade da cultura, da história, do trabalho e das lutas sociais pela transformação da sociedade. (CALDART, 2014) Nesta perspectiva posta, não cabe orientar todo o sistema educativo apenas para o ensino da leitura, da matemática e das ciências medido em testes padronizados, cujas médias de desempenho terminam sendo critério para se definir o que é uma boa educação. A boa educação exige uma matriz alargada de formação que não restrinja as possibilidades de formação humana da juventude.

Ainda em relação a este primeiro par dialético, do ponto de vista da avaliação dos direitos de aprendizagem, enquanto política pública, uma matriz alargada de formação exigirá também uma outra matriz de avaliação, igualmente mais ampla e diversa. Liberta da necessidade de pressionar a escola a conformar-se a decisôes externas, uma avaliação da política pública não precisará ser censitária, 
bastando que seja amostral. Só esta decisão já rompe toda a cadeia de pressóes sobre a escola, liberando seu potencial criativo paralisado pelas avaliaçóes externas e pelas pressóes de responsabilização verticalizadas - uma avaliação amostral não identifica escolas e, portanto, não tem por finalidade padronizar e pressionar a escola e, sim, apenas avaliar a política pública.

A avaliação da escola permanece, mas como uma propriedade da escola que, juntamente com os atores constitutivos desta (pais, gestores, professores e alunos), organiza-se para refletir sobre seu projeto político pedagógico de forma a negociar demandas em duas direçóes: ao poder público naquilo que a ele corresponde, e a si mesma naqueles compromissos locais com a melhoria da qualidade da formação da juventude. Emerge a possibilidade de se construir uma responsabilização participativa. (SORDI; FREITAS, 2013)

O relacionamento fica baseado na confiança profissional mediada por mecanismos de controle locais acompanhados pela comunidade mais próxima. A "sociedade", aqui, está presente através daqueles que têm genuíno interesse na melhoria das crianças: os pais, além das próprias crianças. Deixa de ser uma palavra genérica na qual se escondem atores cujos interesses estão, em verdade, no ajustamento da escola a seus objetivos particulares de acumulação.

Com outro posicionamento para o primeiro par dialético (objetivos/ avaliação) as repercussóes para o segundo par dialético (conteúdos/métodos) também são diferentes. Para o desenvolvimento desta nova matriz não é suficiente uma escola de tempo parcial, professores com qualificação precarizada, ênfases em processos de controle "passo a passo" comandados por avaliaçóes externas que adaptam a escola às funções sociais vigentes, à subordinação, mas a escola deve ser vista como um centro cultural da sua comunidade que investiga a vida e suas contradições sociais, que libera a energia criativa da juventude e a desenvolve em todas as suas dimensóes possíveis, incluindo o domínio sólido do conhecimento das ciências e das artes. Tal é o antagonismo das propostas em curso. A implementação da proposta dos reformadores empresariais - mesmo que conseguisse algum grau de "melhoria" nas escolas baseada na pressão pelo medo -, nos conduzirá a mais da mesma forma de organização do trabalho pedagógico já vista nas escolas, ampliada pela teoria da responsabilização, a qual sufoca atualmente a juventude nas salas de aula, que privilegia a sua adaptação às necessidades do aumento da produtividade das empresas, conduz a uma concepçáo de escola centrada no cognitivo e em testes que legitimam as classificaçôes e ranqueamentos que estimulam a responsabilização e a meritocracia como forma de denegrir a educação pública, conduzindo-a à sua privatização e à precarização do magistério. (RAVITCH, 2011a)

Do ponto de vista do fortalecimento da educação pública, do desenvolvimento de uma matriz formativa ampliada que valorize a formação humana em todas as suas dimensóes, fortaleça o trabalho coletivo, a solidariedade e a 
auto-organização dos estudantes, abrindo possibilidade para o desenvolvimento de novas formas de organização do trabalho pedagógico, a proposta dos reformadores empresariais nos conduzirá a mais uma década perdida. (GUISBOND; NELL; SCHAEFFER, 2012; ROTHSTEIN, 2008; HAGOPIAN, 2014)

\section{Notas}

1. Os antecedentes desta situação incluem o impacto da reestruturaçáo produtiva que redesenhou o trabalho nas organizaçóes sob o comando das tecnologias de informaçáo e comunicaçáo, modelando novos padrões de acumulação de riqueza e novas exigências para a força de trabalho (PُOCHMANN, 2013; ANTUNES, 2004) e estão fora do alcance deste ensaio.

2. Por exemplo, bônus por desempenho, divulgação de médias das escolas em jornais etc. (RAVITCH, 2011a; SOARES; HACHEM, 2010; BRO̧OKE, 2011; MÁXIMO, 2011; CENTRO DE DEBATE DE POLÍTICAS PÚBLICAS, 2014)

3. Corporate reformers - assim são chamados os reformadores empresariais da educação nos Estados Unidos, em termo criado pela pesquisadora americana Diane Ravitch (2011). Ele reflete uma coalizão entre políticos, mídia, empresários, empresas educacionais, institutos e fundações privadas e pesquisadores alinhados com a ideia de que o mercado e o modo de organizar a iniciativa privada é uma proposta mais adequada para "consertar" a educação americana, do que as propostas feitas pelos educadores profissionais.

4. Após a introdução do Ideb a avaliação deixa de ser amostral e passa a ser censitária, ou seja, começa a ser feita em todas as escolas públicas do país.

5. Usando a classificação de Saviani (1983) podemos dizer que a atual escalada das teorias acríticas, de tipo tecnicista com laivos de escolanovismo, é uma resposta ao crescimento das teorias críticas nos anos 1980 e à própria crise mundial dos anos 1970, à qual o capital respondeu formulando a estratégia neoliberal - uma pactuaçáo entre liberais e conservadores (O’CONNOR, 1986) com vistas a recuperar as taxas de acumulação de riqueza já comprometidas naquela década.

6. Esta razão de fundo associa-se a outra, à voracidade do capital em transformar a esfera pública em palco de operaçáo aberto ao mercado educacional, acessando verbas públicas. Sob a denominaçáo de "reformadores empresariais" aglutinam-se interesses diferenciados mas complementares - ideológicos e financeiros.

7. Curiosamente, os reformadores isolam o direito de aprender dos demais direitos. Isso se deve a que, na tese liberal, o direito à educaçáo é um direito "porta de entrada" para os outros. Como o liberal esconde as desigualdades sociais na noçáo de mérito, ele entende que cabe ao Estado "dar a vara", ou seja, a educação, cabendo ao aluno "pescar", ou seja, empenhar-se e obter os demais direitos pelo mérito. Tendo recebido educação e não obtido os outros direitos, pelo menos na proporçáo em que obteve educação, a culpa não é mais do sistema social e sim do próprio indivíduo. No entanto, o que esta tese esconde é que o direito de aprender, depende de outros direitos não disponíveis no ato da aprendizagem por boa parte dos alunos: direito à habitação, à alimentação, à cultura, à saúde etc.

8. No caso brasileiro, a lembrança do "direito de aprender" vem após um ciclo econômico que gerou um alto grau de emprego que elevou em alguns ramos produtivos o salário médio pago, reduzindo lucros. Uma das formas de recompor este quadro é aumentar o número de pessoas "empregáveis" de forma a que a oferta de mão de obra seja maior que a demanda dos empresários, e permita recompor os salários médios em um patamar relativamente mais baixo.

9. O que em tese poderia ser positivo, se não fosse acompanhado da ampliação da "exclusão por dentro" (BOURDIEU; CHAMPAGNE, 2007). Ocorre que as teses dos reformadores náo têm conduzido sequer à redução significativa da segregação acadêmica (ROTHSTEIN, 2008) e, no conjunto, não tem melhorado a qualidade da educação (GUISBOND; NELL; SCHAEFFER, 2012).

10. Deveremos observar isso melhor ao nível do ensino médio com a futura diversificação de modalidades. Trata-se, portanto, de uma versão mais sutil da exclusão e que atende melhor ao atual paradigma de acumulação de riqueza. De fato, o Pronatec é uma antecipação disso. 
11. O mais provável é que estejamos vivendo uma "atualização de distâncias" que, de fato, pouco se reduzem, mas que são transladadas acompanhando o próprio movimento da evolução desigual da acumulaçáo de riquezas, o que tem motivado um frenesi por um "direito de aprender de pernas curtas" que acaba quando o básico é atingido.

12. Há quem defenda que a elaboração da base nacional comum deva ser feita especificando objetivos e conteúdos por bimestres.

13. A aprovação da PEC 82 já institui a meritocracia como princípio a ser observado na constituiçấo do serviço público brasileiro. Também foi igualmente aprovada no âmbito do Plano Nacional de Educação - Lei 13005/2014, na meta 7 como estratégia 7.36.

14. A primeira tentativa de criar uma base nacional comum foi feita via Congresso Nacional mas não foi bem sucedida pois os congressistas não quiseram bancar a obrigatoriedade da base nacional em uma lei. Foi feito, então, um exercício mais bem sucedido de se incluir no Plano Nacional de Educação em vigor, criando, entâo, mecanismos de indução e pactuação para que Estados e Municípios aceitem a base nacional.

15. Não é mera coincidência que os Estados Unidos estejam, neste mesmo momento, implementando também por "pacto" sua base nacional comum conhecida por common core. Obama está aproveitando que os Estados não cumpriram a lei de responsabilidade educacional No Child Left Behind e forçando-os a aceitar a base nacional comum e a utilização dos resultados dos testes como componente da remuneraçáo salarial dos professores (value-added model). Por aqui, o programa do candidato derrotado às eleições presidenciais de 2014, Aécio Neves (PSDB), apontava na mesma direção.

16. Um exemplo desta metodologia operando na área educacional pode ser encontrado em $<$ http:// fundacaolemann.org.br/uploads/estudos/excelencia_com_equidade_qualitativo_e_quantitativo. pdf>. (LEMANN; ITAU) O estudo mostra também como "enfrentar" uma escola que resista às metodologias dos reformadores a partir da mobilização de pais e outros agentes.

17. Quem achou que a onda tecnicista dos anos 1970 com os estudos de Robert Mager (1962) estava superada, enganou-se. Volta revigorada pelos desenvolvimentos ocorridos em várias ciências (TAUBMAN, 2009).

18. Temos conhecimento de escolas inseridas em processos de responsabilização que usam o tempo das disciplinas de história e geografia para reforçar o domínio de leitura e matemática do aluno e, posteriormente, atribuem a todas estas disciplinas a mesma nota que o aluno tira em matemática ou leitura.

19. Sobre esta questão ver a crítica de Jack Block (2010) à teoria dos cinco fatores.

20. As escolas que avançam para alguma organização do trabalho pedagógico diferenciada são as primeiras a serem atingidas e a terem que recuar para a "organizaçáo padrão". O que antes era um "experimento" passa a ser visto como uma ameaça ao bom funcionamento.

21. Redução da formaçáo do professor à base nacional comum curricular e introdução de exames nacionais para seleção de professores, com perspectiva de conversão em formas de certificação profissional para professores e diretores.

22. Ver também <http://www.avaliacaoeducacional.com>.

23. Até mesmo o liberal Ralph Tyler (1978) em seu clássico Princípios Básicos de Currículo e Ensino reconhecia a filosofia como uma das fontes que influenciava a definição dos objetivos de ensino. Como a filosofia não é uma ciência com uma única formulação, cabem escolhas. Portanto, não procede a argumentaçáo de que os reformadores empresariais nâo fazem ideologia, pois mesmo a recusa da ideologia já é uma forma de se fazer ideologia. 


\section{Referências}

ADRIÃO, et al. Uma modalidade peculiar de privatização da educação pública: a aquisição de "sistemas de ensino" por municípios paulistas. Educação e Sociedade, Campinas, v. 30 , n. 108 , p.799-818, out. 2009.

ALEXANDER, K.; ENTWISLE, D.; OLSON, L. The Long Shadow: family background, disadvanteged urban youth and the transition to adulthood. New York: Russell Sage Foundation, 2014.

ALMEIDA, L. C. Relação entre o desempenho escolar de escolas municipais de Campinas e o entorno da escola: a voz dos sujeitos. 2014. Tese (Doutorado em Educação), Faculdade de Educação - UNICAMP, Campinas, (2014).

ANPED. Carta Aberta sobre avaliação em larga escala de habilidades não cognitivas de crianças e jovens. 8 de Novembro de 2014. Disponível em <http://www.anped.org.br/news/ carta-aberta-sobre-avaliacao-em-larga-escala-de-habilidades-nao-cognitivas-de-criancas-e-jovens>.

ANTUNES, R. As mutaçóes no mundo do trabalho na era da mundializaçáo do capital. Educação e Sociedade, Campinas, v. 25, n. 87, p.335-351, maio/ago, 2004.

ARBACHE, J. Brasil precisa elevar produtividade. Folha de São Paulo, p. B4. 7 de janeiro de 2011.

ARROYO, M. G. O direito à educação ameaçado: segregação e resistência. In: ARROYO, M. G.; ABRAMOWICZ, A. A reconfiguração da escola: entre a negação e a afirmação de direitos. Campinas: Papirus, 2009.

AU, W. High-stakes testing and curricular control: a qualitative metasynthesis. Educational Researcher, Washington, DC., v. 36, n. 5, p. 258-267, 2007.

. Unequal by design: High-stakes testing and the standardization of inequality. New York: Routledge, 2009.

BLOCK, J. The five-factor framing of personality and beyond: some ruminations. Psychological Inquiry, Mahwah, v. 21, p. 2-25, 2010.

BLOOM, B. S.; HASTINGS, J. T.; MADAUS, G. F. Handbook on formative and summative evaluation on student learning. New York: MacGraw Hill, 1971.

BOURDIEU, P.; CHAMPAGNE, P. Os excluídos do interior. In: CATANI, M. A. Escritos de Educação. Petropolis: Vozes, 2007.

BROOKE, N. Novas políticas de incentivo salarial para professores: uma avaliação. In: H. FONTOURA, A. Políticas públicas e movimentos sociais: desfios da Pós-Graduação em suas múltiplas dimensóes. Rio de Janeiro: ANPED, 2011.

BRYK, A. S.; SCHNEIDER, B. Trust in Schools: a core resource for improvement. New York: Russell Sage Foundation, 2002.

CALDART, R. Escola em movimento. São Paulo: Expressão Popular, 2014. 
CARLO, M. D. Teachers Matter, But So Do Words. 14 de Julho de 2010. Disponível em http://www.shankerinstitute.org/blog/teachers-matter-so-do-words. Acesso em 25 de Novembro de 2014.

CASTRO, C. M. Escola é empresa? O Estado de São Paulo. Sessão Opinião. 28 de setembro de 2011. Disponível em: <http://opiniao.estadao.com.br/noticias/geral,escola-e-empresa-imp-,778472. Acesso em 12 de Novembro de 2014.

CENTRO DE DEBATE DE POLÍTICAS PÚBLICAS. Sob a Luz do Sol: uma agenda para o Brasil. Disponível em: <http://iepecdg.com.br/uploads/artigos/SobaLuzdoSol_ v0909\%20\%282\%29.docx>. Acesso em 20 de Novembro de 2014.

CHUBB, J. E.; MOE, T. M. Politics, markets and America's shools. Washington: Brookings Institution, 1990.

DEWEY, J.; DEWEY, E. Schools of tomorrow. Witefish: Kessinger Pub, 1915.

DUSSEL, I.; CARUSO, M. A invenção da sala de aula. São Paulo: Moderna, 2003.

EMERY, K. The business roundtable and systemic reform: how corporate-engineered high-stakes testing has eliminated community participation in developing educational goals and policies. 2002. Dissertation (Doctor of Philosophy in Education), University of California, 2002.

ERNICA, M.; BATISTA, A. A Educação em territórios de alta vulnerabilidade social na metrópole: um caso na periferia de SãoPaulo. São Paulo: CENPEC, 2011. [Informe de Pesquisa no. 3].

FREITAS, L. C. Conseguiremos escapar ao neotecnicismo? In: SOARES, M. B.; KRAMER, S.; LUDKE, M. Escola Básica. São Paulo: Anais da 6a. CBE, 1992.

1995.

. Crítica da organização do trabalho pedagógico e da didática. Campinas: Papirus,

. Uma Pós-Modernidade de Libertação: reconstruindo as esperanças. Campinas: Autores Associados, 2005.

. Nas trilhas da exclusão: guetorização, eliminação adiada e mudanças na organização escolar. Propuesta Educativa, Buenos Aires, v. 17, p. 9-31, 2008.

. A luta por uma pedagogia do meio: revisando o conceito. In: PISTRAK, M. M. Escola Comuna. São Paulo: Expressão Popular, 2009.

. Os reformadores empresariais da educação: da desmoralização do magistério à destruição do sistema público de educação. Educação e Sociedade, Campinas, v. 33, n. 119, p. 379-404, 2012.

- Responsabilização, meritocracia e privatização: conseguiremos escapar ao neotecnicismo? In: PINO, I; ZAN, D. (Orgs.). Plano Nacional da Educação (PNE): questóes desafidoras e embates emblemáticos. Brasília: INEP, 2013

- Caminhos da avaliação de sistemas educacionais no Brasil: entre a cultura de auditoria e a cultura da avaliação. In: BAUER, A.; GATTI, B. A. Vinte e cinco anos de avaliação de sistemas educacionais no Brasil. São Paulo: Ed. Insular, 2013 [v. 2, p. 147-176]. 
FREITAS, L. C. Políticas de responsabilização: entre a falta de evidência e a ética. Cadernos de Pesquisa, São Paulo, v. 43, n. 148, p. 348-365, 2013 b.

GUISBOND, L.; NELL, M.; SCHAEFFER, B. A década de progresso educativo perdida sob a NCLB: Que liçóes tirar desse fracasso político? Educação \& Sociedade, Campinas, v. 33, n. 119, p. 405-430, 2012.

HAGOPIAN, J. More than a score: the new uprising against high-stakes testing. Chicago: Haymarket Books, 2014.

FUNDAÇÃO LEMANN; ITAU BBA. Excelência com equidade. São Paulo, s.d. Disponível em <http://www.fundacaolemann.org.br/uploads/arquivos/excelencia_com_equidade. pdf>. Acesso em 6 de Dezembro de 2014.

LIBÂNEO, J. C. Internacionalização das políticas educacionais: elementos para uma análise pedagógica de orientaçóes curriculares para o ensino fundamental e de propostas para a escola pública. In: SILVA, M. A.; CUNHA, C. D. Educação básica: políticas, avanços e pendências. Campinas: Autores Associados, 2014.

MADAUS, G.; RUSSELL, M.; HIGGINS, J. The paradoxes of high stakes testing. Charlotte: Information Age Publishing, 2009.

MAGER, R. Preparing instructional objectives. Atlanta: Certer for Effective Performance Inc., 1962.

MÁXIMO, L. Ganho por meta é foco de estados na educação. Jornal Valor Econômico. 21 de Janeiro de 2011. Disponível em: <http://www.valor.com.br/arquivo/868663/ ganhopor-meta-e-foco-de-estados-na-educacao>. Acesso em 12 de Novembro de 2014.

NEAL, D.; SCHANZENBACH, D. W. Left behind by design: proficiency counts and test-based accountability. Review of Economics and Statistics, Cambridge, v. 92, p. 263-283, 2010.

NICHOLS, S. L.; BERLINER, D. C. Collateral damage: how high-stakes testing corrupts America's schools. Mass: Harvard Educational, 2007.

O’CONNOR, J. Accumulation Crisis. Oxford: Basil Blackwell, 1986.

PARCEIROS DA EDUCAÇÃO. A transformação da qualidade da educaçáo básica no Brasil. 2010. Disponível em: <http://www.parceirosdaeducacao.org.br/evento_propostas/ pdf/transformacao.pdf>. Acesso em 14 de dezembro de 2010.

POCHMANN, M. Desafios do desenvolvimento brasileiro. Educação e Sociedade, Campinas, v. 34, n. 124, p. 705-722, 2013.

RAVITCH, D. Nota mais alta não é educacao melhor. Jornal Estado de São Paulo. 02 de Agosto de 2010. Disponível em: <http://www.estadao.com.br/noticias/impresso,notamais-alta-nao-e-educacao-melhor,589143,0.htm>.

. National opportunity to learn summit. 2011. Disponível em: <http://www.ucc.org/ justice/public-education/pdfs/NatlOTL.pdf>. Acesso em 20 de Outubro de 2014.

. Morte e vida do grande sistema escolar americano. Porto Alegre: Ed. Sulina, 2011a. 
RAVITCH, D. EduShyster Explains the "No Excuses" Model. 5 de January de 2013. Disponível em <http://dianeravitch.net/2013/01/05/edushyster-explains-the-no-excuses-model/>. Acesso em 20 de Outubro de 2014. . Reign of error. New York: Alfred A. Knopf, 2013a.

ROTHSTEIN, R. A "Nation at Risk" Twenty-Five Years Later. 07 de April de 2008. Disponível em <http://www.cato-unbound.org/2008/04/07/richard-rothstein/nation-risk-twenty-five-years-later>. Acesso em 14 de Novembro de 2014.

SAVIANI, D. Escola e Democracia. São Paulo: Ed. Cortez, 1983.

SCHULTZ, T. W. O capital humano: investimentos em educação e pesquisa. Rio de Janeiro: Zahar Ed., 1973.

SHULGIN, V. N. Rumo ao politecnismo. São Paulo: Expressão Popular, 2013.

SOARES, J. S.; HACHEM, Z. I. Gratificação para professores e funcionários de escolas de educação básica: proposta de indicador. In: DALBEN, A. Convergências e tensóes no campo da formação e do trabalho docente. Belo Horizonte: Autêntica, 2010.

SORDI, M. R.; FREITAS, L. C. Responsabilização participativa. Retratos da Escola, Brasília, v. 7, n. 12, p. 87-100, 2013.

TAUBMAN, P. M. Teaching by numbers: deconstructing the discourse of standards and accountability in education. New York: Routledge, 2009.

TYLER, R. Princípios básicos de currículo e ensino. Porto Alegre: Ed. Globo, 1978.

Recebido em 09 de dezembro de 2014.

Aprovado em 27 de fevereiro de 2015. 